Approved Final Technical Report

DOE/I\&I/10520-5

\title{
A New Energy Saving Method of Manufacturing Ceramic Products from Waste Glass
}

\author{
Final Report \\ for the Period March 2000 - July 2002 \\ Michael J. Haun \\ HAUN LABS \\ 122 Calistoga Rd., \#116 \\ Santa Rosa, CA 95409 \\ Tel: 707-538-0584 \\ Email: mjhaun@haunlabs.com
}

Date Published - July 2002

\author{
PREPARED FOR THE UNITED STATES \\ DEPARTMENT OF ENERGY \\ Under Grant No. DE-FG36-00GO10520
}




\section{TABLE OF CONTENTS}

$\underline{\text { Page }}$

I. SUMMARY OF ORIGINAL PROJECT GOALS ......................................... 3

II. VARIANCE FROM PROJECT GOALS ..................................................... 4

III. DISCUSSION OF PROJECT RESULTS ..................................................... 4

A. Phase I Development and Glass Characterization (Tasks 1 and 2) ................ 4

B. Evaluation of Commercial Cullet Sources (Tasks 3 and 4) ......................... 6

C. Phase I Prototype Fabrication and ANSI Testing (Tasks 5 and 6) ................ 7

D. Phase I Demonstration Prototypes and Data Sheets (Task 7) ...................... 9

E. Phase II Process Development and Characterization (Tasks 8 and 9) ........... 9

F. Phase II Prototype Fabrication (Task 10) ................................................ 12

G. Phase II Prototype ANSI Testing (Task 11) .............................................. 12

H. Phase II Demonstration Samples and Data Sheets (Task 12)...................... 14

I. Manufacturing Plant Design / Cost Analysis (Task 13) .............................. 14

J. Market Analysis and Commercialization Planning (Task 14) ...................... 15

K. Project Management and Reporting (Task 15) ........................................ 16

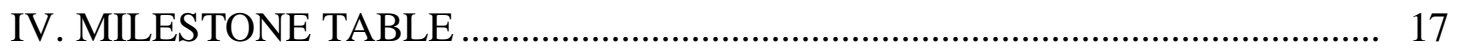

V. ENERGY, ENVIRONMENTAL, AND ECONOMIC SAVINGS ...................... 19

VI. MARKET ESTIMATES / TECHNICAL TRANSFER ACTIVITIES .............. 21 


\section{SUMMARY OF ORIGINAL PROJECT GOALS}

This final report summarizes the activities of the DOE Inventions and Innovations sponsored project, "A New Energy Saving Method of Manufacturing Ceramic Products from Waste Glass." The project involved an innovative method of lowering energy costs of manufacturing ceramic products by substituting traditional raw materials with waste glass. The processing method is based on sintering of glass powder at $\sim 750^{\circ} \mathrm{C}$ to produce products which traditionally require firing temperatures of $>1200^{\circ} \mathrm{C}$, or glass-melting temperatures $>1500^{\circ} \mathrm{C}$.

The key to the new method is the elimination of previous processing problems, which have greatly limited the use of recycled glass as a ceramic raw material. The technology is aligned with the DOE-OIT Glass Industry Vision and Roadmap, and offers significant energy savings and environmental benefits compared to current technologies. A U.S. patent $(\# 6,340,650)$ covering the technology was issued on January 22, 2002. An international PCT Patent Application is pending with designations made for all PCT regions and countries.

The goal of the project was to provide the basis for the design and construction of an energy-efficient manufacturing plant that can convert large volumes of waste glass into high-quality ceramic tile. The main objectives of the project were to complete process development and optimization; construct and test prototype samples; and conduct market analysis and commercialization planning.

Two types of ceramic tile products were targeted by the project. The first type was developed during the first year (Phase I) to have a glazed-like finish for applications where slip resistance is not critical, such as wall tile. The processing method optimized in Phase I produces a glossy surface with a translucent appearance, without the extra glazing steps required in traditional tile manufacturing. The second type of product was developed during the second year (Phase II). This product was designed to have an unglazed appearance for applications requiring slip resistance, such as floor tile. The coarser matte finish of this product type was produced by modifying the basic process to include crystalline fillers and partial crystallization of the glass. Additional details of the project results are discussed in Section III. 


\section{VARIANCE FROM PROJECT GOALS}

Overall the project goals were completed as planned and on schedule. The only major variance occurred during the second year. The success of the ANSI test results at the end of the first year allowed additional marketing and commercialization planning to be conducted in place of most of the Phase II characterization work. This also allowed the manufacturing plant design and cost analysis work to begin earlier than originally planned.

\section{DISCUSSION OF PROJECT RESULTS}

The project was divided into 15 tasks as listed in the Milestone Table on p.18. The project results are summarized in the following sections for each of these tasks.

\section{A. Phase I Development and Glass Characterization (Tasks 1 and 2)}

The Phase I research focused on optimizing the process variables. A series of interrelated experimental studies investigated the effects of glass composition, contaminants, glass powder particle size, binder system, pressing pressure, and firing conditions on the densification behavior of tile samples. The results of these studies are summarized in the following paragraphs.

The effect of moisture (considered a contaminant to the process) on the densification behavior as a function of glass particle size was investigated. Three glass particle size ranges were prepared from crushed clear glass containers, and subjected to three moisture levels to produce nine variations. The results provide important data on how finely the glass can be crushed and ground before drying is necessary. When coarse glass particles (>30 mesh) were exposed to water, and then subsequently dried and processed, the densification behavior was not affected. This result indicates that commercial cullet will be an acceptable raw material, even if it has been exposed to water.

When finer particles ( $<30$ mesh) were exposed to water, the densification behavior was adversely affected. However, this greatly depended on the type of moisture exposure, and can be correlated to the concentration and $\mathrm{pH}$ of the water present, and also to the type of binder and method of binder addition. These results confirm the adverse affects of water, and demonstrate the need for dry processing below a specific particle 
size range. The results of this study were used to establish a standard drying, crushing, and grinding procedure for the remaining studies.

The effect of glass powder particle size on the pressing and firing processes was investigated for three particle size ranges with a fixed binder system. As the particle size was decreased the quality of both pressed and fired samples improved. This study provided data on the range of firing conditions (heating rate, maximum temperature, and hold time) that will be required. These results indicate that a very rapid firing process will be possible with a maximum temperature of $\angle 800^{\circ} \mathrm{C}$ and hold time of only five minutes.

The effect of inorganic contaminants on the densification behavior of fine glass powder was investigated. Five contaminants were added in three amounts to produce fifteen combinations. The densification behavior was not significantly affected with one weight percent additions. With higher contaminant levels of five and twenty percent, the densification was affected, but this greatly depended on the type of contaminant. These results indicate that small amounts of inorganic contaminants, when finely ground, will not significantly affect the densification behavior. However, the color and surface texture of the samples were affected, at least slightly, for all variations studied.

Studies were conducted to optimize the binder system and pressing conditions. Measurement of the green strength and density was used to evaluate the binder system and pressing variables. A diametral compression test fixture was setup to measure the tensile green strength of pressed cylindrical samples. Measurements with this fixture agree well with literature results.

The green strength and density were measured as a function of variations in binder type, percentage, and molecular weight, and also pressing pressure and hold time. The green density and strength increased with increasing pressing pressure, and depended greatly on the binder system. The hold time during the pressing process was found to have only a small effect on the green density and strength. This result indicates that a rapid pressing operation with a short hold time is possible. Based on these results a binder system was selected to fabricate the Phase I prototype tile samples.

Particle size, surface area, and differential thermal analysis (DTA) were measured on glass powders by Corning Laboratory Services (Corning, NY), and x-ray diffraction (XRD) and x-ray fluorescence (XRF) by the Mineral Lab (Lakewood, CO). The DTA results clearly show the glass transition region, and correlate well with the firing studies. These data are important for characterizing the glass powders of the current study, and for comparison with future glass powders. XRD and XRF were conducted on additional 
fired samples to initially characterize the crystallization behavior. The crystallization behavior was found to depend on the composition and firing conditions.

The effect of contaminants from glass container labels on the processing conditions and fired samples was investigated. Glass powders were prepared from clear, green, and amber colored glass containers without removing the paper labels. Most of paper can be removed during the crushing, grinding, and sieving steps. However, for this study the amount of contaminant was varied by sieving with different mesh sizes, so that potential adverse effects could be identified.

With a high amount of contaminant and fast firing conditions, fired defects occurred in samples, because of incomplete burnout prior to sintering of the glass. The results indicate that both the amount of paper label contaminants and firing conditions will need to be carefully controlled to prevent fired defects from occurring. This investigation completed the Phase I development work to optimize the process variables. The optimized procedures were then used to evaluate commercial cullet sources, and to prepare prototype samples for ANSI testing, as discussed in the following sections.

\section{B. Evaluation of Commercial Cullet Sources (Tasks 3 and 4)}

Eight commercially available glass cullet sources were evaluated by processing samples according to the optimized procedures from the Phase I development work. These cullet sources represented a wide range of particle sizes from coarse $(<5 / 8$ inch) to very fine $(<200 \mathrm{mesh})$. The type of cullet source also varied significantly with clear, green, and mixed-color container glass, and clear flat glass evaluated. The results demonstrate that commercially available cullet can be processed into dense tile samples, if the particle size of the cullet source is not too fine.

Five of the eight cullet sources were selected for characterization by external labs (Task 4). Samples were sent to Corning for DTA, PSD, and SA, and to the Mineral Lab for XRF. The results for container glass cullet sources were similar to the Phase I characterization results. However, the flat glass cullet sources showed differences in composition and particle size distributions, which correspond to slight differences in processing behavior. Two of the cullets with excellent densification results (a mixedcolor container glass, and a flat glass), were selected for use in fabricating prototype samples for ANSI testing. 


\section{Phase I Prototype Fabrication and ANSI Testing (Tasks 5 and 6)}

The required sample sizes and quantities for the ANSI testing, based on the Tile Council of America requirements and the most recent versions of the ASTM test procedures, were first determined. Firing studies were then conducted to determine fired shrinkages as a function of pressing conditions and sample size. These data were used to design metal pressing dies for three tile sizes; $1 \times 1,1 \times 4.25$, and $4.25 \times 4.25$ (dimensions in inches). Test samples were fabricated from $100 \%$ recycled glass from two commercial cullet sources, Type A (mixed-color container glass) and Type B (clear flat glass). Over 200 samples were processed, with 190 sent to the Tile Council of America for ANSI testing.

The results of the ANSI testing are summarized in Table I. The test methods are listed, along with the ANSI specifications, if available. The results for Type A and B samples are listed. The moisture expansion and water absorption values were very low, because of the near zero porosity levels of the samples. Tile with water absorptions less than $0.5 \%$ are classified as impervious, which is a requirement for porcelain tile. The results of the next three tests listed (bond strength, abrasion resistance, and breaking strength) all easily exceeded the ANSI specifications. Chemical resistance testing was conducted with 15 different chemicals, including hydrochloric acid and potassium hydroxide. The tiles showed no effect to all of the chemicals tested. This is a very significant result considering that the samples were made from $100 \%$ commercial recycled soda-lime silicate glass. Modulus of rupture values were high. Freeze-thaw cycling did not affect the samples.

A second abrasion resistance test was conducted, which is specifically for glazed tile. This test divides abrasion resistance into five classes from 1 to 5 with Class 1 having the least abrasion resistance, and Class 5 having the most. Class 3 is considered to be needed for floor tile applications. The Type A tile were rated Class 2, and thus would be acceptable for wall tile, but probably not for floor tile. Type B were rated Class 3, which was a surprising result considering the tile were made from $100 \%$ glass without any abrasive filler material added. The difference in performance between Type A and B is believed to be because of particle size differences, and not because of the glass type.

The coefficient of friction was tested with the samples dry and wet. A value greater the 0.5 is considered to be needed for floor tile applications. The dry values greatly exceeded this, but the wet values were borderline. The phase II work during the second year focused on improving the slip resistance (discussed in Section III.E). The scratch hardness was also measured based on the Mohs' hardness scale with values ranging from 1 (talc) to 10 (diamond). Both Type A and B had values of 5. 


\section{Table I - Property Data for Ceramic Tiles made from $100 \%$ Recycled Glass}

(All testing conducted by the Tile Council of America)

\begin{tabular}{|l|c|c|c|c|}
\hline \multicolumn{1}{|c|}{$\begin{array}{c}\text { Test } \\
\text { Description }\end{array}$} & $\begin{array}{c}\text { Test } \\
\text { Method }\end{array}$ & $\begin{array}{c}\text { ANSI A137.1 } \\
\text { Specification }\end{array}$ & $\begin{array}{c}\text { Type A* } \\
\text { Tile Results }\end{array}$ & $\begin{array}{c}\text { Type B** } \\
\text { Tile Results }\end{array}$ \\
\hline Moisture Expansion & ASTM C370 & No spec given & $0.005 \%$ & $0.012 \%$ \\
\hline Water Absorption & ASTM C373 & $\begin{array}{c}<0.5 \% \text { for } \\
\text { Porcelain Tile }\end{array}$ & $0.05 \%$ & $0.05 \%$ \\
\hline Bond Strength & ASTM C482 & $>50$ psi & 166 psi & 155 psi \\
\hline Abrasion Resistance & ASTM C501 & $\begin{array}{c}\text { Index of }>100 \text { for } \\
\text { Porcelain Tile }\end{array}$ & 153 & 167 \\
\hline Breaking Strength & ASTM C648 & $>250$ lbs & 609 lbs & 571 lbs \\
\hline Chemical Resistance & ASTM C650 & $\begin{array}{c}\text { No effect to a wide } \\
\text { range of chemicals }\end{array}$ & Passed & Passed \\
\hline Modulus of Rupture & ASTM C674 & No spec given & 8900 psi & 8000 psi \\
\hline $\begin{array}{l}\text { Abrasion Resistance } \\
\text { of Glazed Tile }\end{array}$ & ASTM C1027 & No spec given & Class 2 & Class 3 \\
\hline Freeze-Thaw Cycling & ASTM C1026 & No cracking, etc. & Passed & Passed \\
\hline $\begin{array}{l}\text { Coefficient of } \\
\text { Friction }\end{array}$ & ASTM C1028 & No spec given & $\begin{array}{c}\text { Dry: } 0.90-0.99 \\
\text { Wet: } 0.47-0.49\end{array}$ & $\begin{array}{c}\text { Dry: } 0.88-0.96 \\
\text { Wet: } 0.47-0.49\end{array}$ \\
\hline Scratch Hardness & MOH's Scale & No spec given & 5 & 5 \\
\hline
\end{tabular}

*Type A tiles were made from recycled mixed-color container glass.

**Type B tiles were made from recycled clear flat glass. 
One additional test was also conducted by the Tile Council of America, Thermal Shock Resistance (ASTM C484). This test consists of cycling samples back and forth ten times between an oven at $293^{\circ} \mathrm{F}$ and a container of water at $59^{\circ} \mathrm{F}$. Both tile types cracked after the first cycle, which indicates that the $100 \%$ recycled glass tiles may not be suitable for kitchen counter top or other applications requiring good thermal shock resistance. However, there are companies that sell glass based tiles and claim in their literature that the thermal shock resistance is excellent. Thermal shock testing was conducted at Haun Labs to compare these commercial tiles with the Type A and B tile. The commercial glass tiles tested also failed the ASTM test. Part of the Phase II work focused on improving the thermal shock resistance through the addition of crystalline fillers and/or crystallization, as discussed in Section III.E.

The Phase I ANSI results confirm that the prototype samples made from $100 \%$ recycled waste glass are suitable for wall tile, swimming pools, and other types of tile applications. This work completed the first year of the project, and demonstrated that the basic processing method can be used to produce high-quality ceramic tile from commercially available cullet from both container and flat glass sources.

\section{Phase I Demonstration Prototypes and Data Sheets (Task 7)}

Demonstration prototypes and data sheets of the ANSI results were prepared, along with a photo sheet showing the range of colors initially produced. A wide range of colors were developed as part of the initial Phase II work (discussed in the next section). This information with prototype samples and the DOE Fact Sheet were displayed at the OIT Industrial Energy Efficiency Symposium, February 19-21, 2001 in Washington, DC as part of the Inventions and Innovations "Bringing Technologies to Market" booth. Many samples and data sheets were distributed to the attendees at the Expo, and at the following Glass Industry Workshop on February 22, 2001. Additional samples and data sheets were also sent out by mail. Information and sample display boards were also prepared, with one set sent to the DOE Project Officer, Gibson Asuquo, at the Golden Field Office.

\section{E. Phase II Process Development and Characterization (Tasks 8 and 9)}

Phase II process development was conducted to expand the basic processing method, optimized in Phase I, to include methods of controlling the surface finish, texture, and color. The surface finish and texture were adjusted by addition of crystalline fillers and by partial crystallization of the glass to produce a glass-ceramic 
microstructure. These methods also enhance other properties, such as slip resistance, thermal shock resistance, and mechanical properties.

Initial color studies were conducted to investigate the addition of commercially available ceramic stains. Eighteen stains were evaluated. These stains or colorants are typically used to produce colors in ceramic glazes, but can also be used in clay-based ceramic tile bodies. In clay-based tiles these stains produce a dull matte appearance, compared to in glazes where a glossy appearance occurs. When added to recycled glass powder, ceramic stains tend to produce a glossy appearance with small additions, and more of a matte finish as the amount of colorant is increased. This initial work demonstrated that a wide range of colors can be produced. Variations in the amount of stain added indicated that only small amounts are needed to produce effective colors. Variations in processing conditions also indicated that only short mixing times are necessary to produce uniform colors throughout the tile samples.

The effect of filler additions on the densification behavior and surface texture was investigated. The results greatly depend on the type of filler, and appear to correlate with the dissolution rate of the filler in glass. Fillers with high dissolution rates result in a more homogeneous appearance, and a smoother surface texture. Fillers with low dissolution rates create a heterogeneous speckled appearance, and a rougher surface texture. Larger amounts of fillers with high dissolution rates can be added, without significantly affecting the densification behavior, compared to fillers with low dissolution rates.

Variations in glass particle size can be used to control the surface roughness and appearance. However, increasing the particle size too much will adversely affect the green strength of pressed samples. Speckled color patterns were achieved by using combinations of different types of glass, particle sizes, and crystalline fillers. These results indicate that a product type can be developed with less sensitivity to variations in glass cullet color and quality. This is a very significant result, because large quantities of recycled glass become too contaminated to be remelted into new glass products, but could be used in a ceramic tile product with multi-colored speckled patterns.

X-ray diffraction was used to characterize the crystallization behavior of samples fired to a series of temperatures. The results show that crystallization correlates with a roughing of the surface texture. These results indicate that the firing process can be varied to promote partial crystallization of the glass, which results in a roughing of the surface texture and improved slip resistance for floor tile applications. 
X-ray diffraction was also used to investigate the effect of a wide range of filler additions on crystallization. The crystallization behavior was found to depend on the type of waste glass, particle size of the glass powder, type of filler addition, and firing conditions. Some of the filler additions dissolved into the glass during firing, while others did not. Dissolution of the filler did not always correlate with the surface roughness. In some cases fillers which dissolved into the glass still produced roughened surfaces, even without crystallization of the glass. Colorant filler additions were found to result in crystalline phases after firing, which appear to be due to the colorant additions, and not because of crystallization of the glass.

Thermal shock resistance was evaluated on a wide variety of samples to determine the effect of tile size, and variations in filler amount and type. Thermal shock resistance was previously found to be a potential limitation of $100 \%$ recycled glass tiles during the ANSI testing conducted by the Tile Council of America. The ASTM C484 test procedure was used which consists of cycling samples back and forth ten times between an oven at $293^{\circ} \mathrm{F}$ and a container of water at $59^{\circ} \mathrm{F}$. This procedure was modified in the recent testing to more quantitatively compare variations in thermal shock resistance. This was done by cycling the test samples back and forth between water at $59^{\circ} \mathrm{F}$, and a series of oven temperatures starting at $110^{\circ} \mathrm{F}$. The oven temperature was then increased in ten steps to $360^{\circ} \mathrm{F}$.

All of the samples withstood cycling to the first five temperatures without cracking. Cycling to higher temperatures then caused samples to crack depending on the sample size and filler addition. Smaller samples had better thermal shock resistance compared to larger samples. Small additions of most of the fillers investigated, including colorants, greatly improved the thermal shock resistance. Increasing the filler addition further improved the thermal shock resistance. Samples with the largest addition of filler even withstood cycling to the highest temperature of $360^{\circ} \mathrm{F}$ without cracking.

The results of the Phase II development work provided additional understanding on methods for controlling the surface finish, texture, and color. Formulations with improved abrasion resistance and slip resistance for floor tile applications were developed based on these data. The results also demonstrate that improved thermal shock resistance can be achieved. Selected formulations were used to produce prototype samples for ANSI standards testing, as discussed in the following section. 


\section{F. Phase II Prototype Fabrication (Task 10)}

Over 500 Phase II prototype samples were processed and sent to the Tile Council of America for ANSI Ceramic Tile Standards testing. The samples were made from four formulations with different combinations of waste glass cullet and filler additions. Container glass was used in two of the formulations, and flat glass used in the other two. Colorant and other ceramic filler additions were included to control the color and surface appearance. Two of the formulations were specifically designed to improve abrasion and slip resistance for floor tile applications.

\section{G. Phase II Prototype ANSI Testing (Task 11)}

The Tile Council of America conducted ANSI testing on the Phase II prototype tile samples. The results are summarized in Table II. The test methods are listed, along with the ANSI specifications, if available. The results are listed for glossy and matte tile surfaces based on the test data of the four sets of Phase II results. The previous two sets of Phase I results are similar to the glossy tile results listed in Table II. The Phase I samples were made from $100 \%$ waste glass without any filler additions. The Phase II results confirm that small additions of colorants do not significantly affect the properties. Small amounts of other types of fillers were used to produce matte tile surfaces with improved properties for floor tile applications. The matte tiles resulted in enhanced properties, as discussed below.

The moisture expansion and water absorption values were very low, because of the near zero porosity levels of the samples. The results of the next three tests listed (bond strength, abrasion resistance, and breaking strength) all easily exceeded the ANSI specifications. The greater filler additions in the tiles with matte surfaces further enhanced these properties, compared to the glossy surface tiles which had less filler addition.

Chemical resistance testing was conducted with 15 different chemicals, including hydrochloric acid and potassium hydroxide. The tiles showed no effect to all of the chemicals tested. Modulus of rupture values were high. Freeze-thaw cycling did not affect the samples.

The coefficient of friction was tested with the samples dry and wet. A value greater than 0.5 is considered to be needed for floor tile applications. For the glossy tiles the dry values were significantly greater than 0.5 , but the wet values ranged from 0.41 0.49 . These results indicate that the glossy tiles are suitable for wall tile, but probably not 


\section{Table II - Property Data for Ceramic Tiles made from $>92 \%$ Recycled Glass}

(All testing conducted by the Tile Council of America)

\begin{tabular}{|c|c|c|c|c|}
\hline $\begin{array}{c}\text { Test } \\
\text { Description }\end{array}$ & $\begin{array}{c}\text { Test } \\
\text { Method }\end{array}$ & $\begin{array}{l}\text { ANSI A137.1 } \\
\text { Specification }\end{array}$ & $\begin{array}{c}\text { Glossy } \\
\text { Tile Results }\end{array}$ & $\begin{array}{c}\text { Matte } \\
\text { Tile Results }\end{array}$ \\
\hline Moisture Expansion & ASTM C370 & No spec given & $<0.02 \%$ & $<0.02 \%$ \\
\hline Water Absorption & ASTM C373 & $\begin{array}{l}<0.5 \% \text { for } \\
\text { Porcelain Tile }\end{array}$ & $<0.1 \%$ & $<0.1 \%$ \\
\hline Bond Strength & ASTM C482 & $>50 \mathrm{psi}$ & $>150 \mathrm{psi}$ & $>200 \mathrm{psi}$ \\
\hline Abrasion Resistance & ASTM C501 & $\begin{array}{c}\text { Index of }>100 \text { for } \\
\text { Porcelain Tile }\end{array}$ & $>100$ & $>150$ \\
\hline Breaking Strength & ASTM C648 & $>250 \mathrm{lbs}$ & $>500 \mathrm{lbs}$ & $>600 \mathrm{lbs}$ \\
\hline Chemical Resistance & ASTM C650 & $\begin{array}{l}\text { No effect to a wide } \\
\text { range of chemicals }\end{array}$ & Passed & Passed \\
\hline Modulus of Rupture & ASTM C674 & No spec given & $>7,000 \mathrm{psi}$ & $>8,000 \mathrm{psi}$ \\
\hline Freeze-Thaw Cycling & ASTM C1026 & No cracking, etc. & Passed & Passed \\
\hline $\begin{array}{l}\text { Coefficient of } \\
\text { Friction }\end{array}$ & ASTM C1028 & No spec given & $\begin{array}{l}\text { Dry: }>0.7 \\
\text { Wet: }>0.4\end{array}$ & $\begin{array}{l}\text { Dry: }>0.8 \\
\text { Wet: }>0.6\end{array}$ \\
\hline Scratch Hardness & Mohs' Scale & No spec given & 5 & 5 \\
\hline
\end{tabular}


for floor tile. The tiles with mattes surfaces had significantly enhanced slip resistance with dry values greater than 0.8 , and wet values greater than 0.6. One of the matte tile types even had wet values as high as 0.84 . These results indicate that the matte tiles are suitable for floor tile applications.

The scratch hardness was also measured based on the Mohs' hardness scale with values ranging from 1 (talc) to 10 (diamond). Both types of tile had values of 5 . One additional test was also conducted by the Tile Council of America, Thermal Shock Resistance (ASTM C484). The Phase II thermal shock results were improved compared to the Phase I results, however internal microcracks still occurred. These results indicate that higher filler additions may be needed to further improve the thermal shock resistance for special applications. However, for most tile applications these tiles will be acceptable.

\section{H. Phase II Demonstration Samples and Data Sheets (Task 12)}

Phase II demonstration samples and data sheets of the ANSI results were prepared. This information was distributed at the Coverings International Ceramic Tile Trade Show in Orlando, FL on May 6-9, 2002. Sample display boards showing the Phase II samples were also prepared. A display board showing both glossy and matte samples was sent to the DOE Project Officer, Gibson Asuquo, at the Golden Field Office. Additional display boards with glossy samples were sent to several other DOE personnel.

\section{Manufacturing Plant Design / Cost Analysis (Task 13)}

An initial design for a highly-automated ceramic tile plant was developed. This relatively small plant will produce 500,000 square feet of tiles per year using 1000 tons of recycled glass. The major steps of the process are glass crushing/milling, batching/mixing, pressing, and firing. Ceramic equipment companies were contacted about potential manufacturing equipment for each of the processing steps. The plant size can easily be adjusted by varying the size of the equipment used. The cost of the equipment per unit of tile produced will decrease as the plant size is increased.

A comparison of the differences in processing steps and costs between the new technology and traditional ceramic tile processing was conducted. The manufacturing costs with the new technology are lower, because traditional raw materials are replaced with waste glass; process energy is reduced; major processing steps are eliminated; and 
equipment costs and maintenance expenses greatly reduced. In addition to lower manufacturing costs, a high-quality "green" product is produced, which will sell for a premium price.

Calculations of the energy and associated cost savings of the new technology compared to current ceramic tile manufacturing were also conducted. The results and discussion of the calculations are presented below in Section V.

\section{J. Market Analysis and Commercialization Planning (Task 14)}

A variety of market analysis and commercialization planning activities were conducted during the project. Data on recycled glass products and companies, and on the ceramic tile industry were collected and organized to assist with a Market Assessment for the project. This Market Assessment was completed by New Horizon Technologies. The report provides very useful and promising market information. The executive summary of the report concluded: "The ceramic-tile market is seeing double-digit increases in demand. Prices for ceramic tile are dropping while the costs of fuel and raw materials are rising. These market trends create a favorable environment for the subject technology. If the barriers to adapting the new processing technology can be overcome, it appears the subject technology will have an excellent market opportunity."

Additional ceramic tile market data was collected, along with information on the construction and manufacturing costs of ceramic tile production. These data were used to further develop a detailed commercialization plan for the technology with initial timing and cost estimates. The two-year plan mainly focuses on commercial product development, marketing studies, and construction of a demonstration plant.

The Principal Investigator attended various workshops, conferences, and trade shows during the project. A DOE Commercialization Strategy Workshop on March 2122, 2000 provided useful information, which was used as a guide to further develop the commercialization plan. The principal investigator also attended an Environmental Capital Network (ECN) Raising Capital Seminar on October 11-12, 2000, which provided additional commercialization planning information.

The principal investigator attended the OIT Industrial Energy Efficiency Symposium, February 19-21, 2001 in Washington, DC, and displayed information and prototype samples as part of the Inventions and Innovations "Bringing Technologies to Market" booth. Many samples and data sheets were distributed to the attendees at the Expo, and at the following Glass Industry Workshop on February 22, 2001. 
A Recycled Products Trade Show was attended in Sacramento, CA on April 11, 2001. Project fact sheets, data sheets, and prototype samples were distributed to interested attendees at the show. The technology and commercialization strategies were discussed with several California State employees from the Departments of Conservation and Energy, and the Integrated Waste Management Board. An Architect from the CA Parks Department stated that they were looking for construction materials made from recycled products, and currently have several projects where recycled-glass tiles could be used.

The principal investigator attended the National Recycling Coalition Annual Conference and Exposition on January 15-16, 2002 in Seattle, WA to learn more about potential market opportunities for the technology. A local glass manufacturing company and three recycled-glass processors were also visited during the trip.

The principal investigator attended the Coverings International Ceramic Tile Trade Show in Orlando, FL on May 6-9, 2002. Coverings is the worlds largest annual ceramic tile trade show. Over 30,000 visitors attended from 101 countries. Project information was distributed to selected tile companies which expressed interest in the technology. Commercialization of the technology with these companies is currently being investigated.

\section{K. Project Management and Reporting (Task 15)}

The project status and expenditures were summarized each month in an Appendix to the Monthly Invoices (Standard Form 270). Four semi-annual reports were also written during the project. 


\section{MILESTONE TABLE}

An updated Milestone Table is shown in Table III. The following Milestone Notes correspond to the table:

?? Note 1 - Tasks 1-7 (Phase I work) were completed with a total cost of $\$ 75,818.60$ compared to the original projected cost of $\$ 79,729.00$. Tasks 8-12 (Phase II work) were completed with a total cost of $\$ 75,526.00$ compared to the original projected cost of $\$ 86,648.00$. The reduced costs for Phases I and II were balanced by additional spending on Task 14 (Market Analysis and Commercialization Planning).

?? Note 2 - The cost of the ANSI testing (Tasks 6 and 11) was reduced by 20\%, because of a multiple test discount.

?? Note 3 - Task 9 costs were significantly reduced, because of the success of the ANSI results from Phase I. These savings were used to expand Task 14 (Market Analysis and Commercialization Planning).

?? Note 4 - Manufacturing plant design and cost analysis was started in April 2001, earlier than originally scheduled.

?? Note 5 - Market analysis and commercialization planning activities were expanded as discussed above in Notes 1 and 3. Additional details are provided in Sections II and III.

?? Note 6 - Project management and reporting activities were conducted throughout the project, as discussed in Section III.K.. 


\section{Table III - MILESTONE TABLE}

\begin{tabular}{|c|c|c|c|c|c|c|c|c|}
\hline & Milestone Title & $\begin{array}{c}\text { Original } \\
\text { Planned } \\
\text { Completion } \\
\text { Date }\end{array}$ & $\begin{array}{c}\text { Revised } \\
\text { Planned } \\
\text { Completion } \\
\text { Date }\end{array}$ & $\begin{array}{c}\text { Actual } \\
\text { Completion } \\
\text { Date }\end{array}$ & $\begin{array}{l}\text { Responsible } \\
\text { Organization }\end{array}$ & $\begin{array}{c}\text { Original } \\
\text { Projected } \\
\text { Cost }\end{array}$ & $\begin{array}{l}\text { Revised } \\
\text { Projected } \\
\text { Cost }\end{array}$ & $\begin{array}{r}\text { Actua } \\
\text { Comple } \\
\text { Cost }\end{array}$ \\
\hline 1 & $\begin{array}{l}\text { Phase I development (optimization of } \\
\text { process variables) }\end{array}$ & $10 / 31 / 00$ & & $10 / 31 / 00$ & Haun Labs & $48,000.00$ & & $39,12 \mathrm{C}$ \\
\hline 2 & $\begin{array}{l}\text { Glass powder characterization (PSD, } \\
\text { SA, DTA, XRF) }\end{array}$ & $5 / 31 / 00$ & $10 / 31 / 00$ & $11 / 9 / 00$ & External Labs & $4,220.00$ & $3,635.00$ & 3,635 \\
\hline 3 & $\begin{array}{c}\begin{array}{c}\text { Evaluation of commercial cullet } \\
\text { sources }\end{array} \\
\end{array}$ & $12 / 31 / 00$ & & $12 / 31 / 00$ & Haun Labs & $8,000.00$ & & $9,92 \mathrm{C}$ \\
\hline 4 & $\begin{array}{c}\text { Cullet characterization (PSD, SA, } \\
\text { DTA, XRF) }\end{array}$ & $11 / 30 / 00$ & & $2 / 1 / 01$ & External Labs & $3,025.00$ & & $3,00 \mathrm{C}$ \\
\hline 5 & Phase I prototype fabrication & $1 / 31 / 01$ & & $1 / 31 / 01$ & Haun Labs & $6,000.00$ & & $9,84 \mathrm{C}$ \\
\hline 6 & Phase I prototype ANSI testing & $2 / 28 / 01$ & & $2 / 23 / 01$ & $\begin{array}{l}\text { Tile Council } \\
\text { of America }\end{array}$ & $5,684.00$ & & $\overline{4,543}$ \\
\hline 7 & $\begin{array}{l}\text { Phase I demonstration prototypes and } \\
\text { data sheets available }\end{array}$ & $2 / 28 / 01$ & & $2 / 28 / 01$ & Haun Labs & $4,800.00$ & & $5,76 \mathrm{C}$ \\
\hline 8 & $\begin{array}{l}\text { Phase II development (crystallization, } \\
\text { fillers, and colorants) }\end{array}$ & $10 / 31 / 01$ & & $10 / 31 / 01$ & Haun Labs & $48,000.00$ & & 42,000 \\
\hline 9 & $\begin{array}{c}\text { Characterization of crystallization } \\
\text { behavior (DTA, XRD) }\end{array}$ & $7 / 31 / 01$ & $10 / 31 / 01$ & $10 / 31 / 01$ & External Labs & $13,680.00$ & & $1,15 \mathrm{C}$ \\
\hline 10 & Phase II prototype fabrication & $12 / 31 / 01$ & & $1 / 14 / 02$ & Haun Labs & $9,600.00$ & & $19,52 \mathrm{C}$ \\
\hline 11 & Phase II prototype ANSI testing & $1 / 31 / 02$ & & $3 / 18 / 02$ & $\begin{array}{l}\text { Tile Council } \\
\text { of America }\end{array}$ & $11,368.00$ & $9,094.40$ & 8,216 \\
\hline 12 & $\begin{array}{l}\text { Phase II demonstration prototypes } \\
\text { and data sheets available }\end{array}$ & $2 / 28 / 02$ & & $3 / 27 / 02$ & Haun Labs & $4,000.00$ & & $4,64 \mathrm{C}$ \\
\hline 13 & $\begin{array}{l}\text { Manufacturing plant design/cost } \\
\text { analysis }\end{array}$ & $6 / 30 / 02$ & & $5 / 31 / 02$ & Haun Labs & $9,600.00$ & & $9,84 \mathrm{C}$ \\
\hline 14 & $\begin{array}{l}\text { Market analysis and } \\
\text { commercialization planning }\end{array}$ & $8 / 31 / 02$ & & $5 / 31 / 02$ & Haun Labs & $12,000.00$ & & $24,00 \mathrm{C}$ \\
\hline 15 & Project management and reporting & $8 / 31 / 02$ & & $5 / 31 / 02$ & Haun Labs & $12,000.00$ & & 14,792 \\
\hline
\end{tabular}




\section{ENERGY, ENVIRONMENTAL, AND ECONOMIC SAVINGS}

The project technology was used to design a manufacturing process for producing ceramic tiles, as discussed in Section III.I. The energy, environmental, and economic savings result mainly from replacing traditional ceramic raw materials with waste glass, which lowers the firing temperature by $37 \%$ compared with clay-based tiles (firing to $750^{\circ} \mathrm{C}$ versus $1200^{\circ} \mathrm{C}$ ). Table IV summarizes the savings which result from the new technology compared to traditional clay-based ceramic tile manufacturing. Ceramic tile manufacturing plants range from small scale with production levels of less than one million sq.ft./yr to large plants with greater than ten million sq.ft./yr. A process producing one million sq.ft./yr was chosen as the installed unit for analysis of both traditional manufacturing and the new technology.

Data from the 1997 Economic Census on Ceramic Wall and Floor Tile Manufacturing from the U.S. Dept. of Commerce were used to determine the energy consumption of current ceramic tile manufacturing processes. These data indicate that for each square foot of tile manufactured 13,300 Btu are consumed from fuel usage (mainly natural gas for firing). The new technology results in a $37 \%$ savings in fuel costs, which reduces energy consumption from 13.3 billion Btu/yr/unit for traditional processing to 8.4 billion Btu/yr/unit. This is a savings of 4.9 billion Btu/yr/unit.

Environmental savings result from substitution of traditional ceramic raw materials (clay, flint, feldspar, etc.) with waste glass. 100\% substitution is used in the calculations, however typically $1-8 \%$ colorants and other fillers will be added depending on the surface appearance desired. For each installed unit producing one million sq.ft. of tiles, 2000 tons of raw material is required (assuming $4 \mathrm{lbs} / \mathrm{sq} . \mathrm{ft}$.). Thus, the new technology utilizes 2000 tons/yr/unit of waste glass in place of 2000 tons/yr/unit of traditional raw materials. In addition to reducing landfill disposal of waste glass, the new technology eliminates the need for mining, processing, and transportation of traditional raw materials.

Environmental savings also result from reduced $\mathrm{CO}_{2}$ emissions, because of lower firing temperatures and less natural gas usage. With traditional ceramic tile manufacturing 779 tons of $\mathrm{CO}_{2} / \mathrm{yr} / \mathrm{unit}$ of emissions results from fuel consumption, compared to 491 tons of $\mathrm{CO}_{2} / \mathrm{yr} / \mathrm{unit}$ for the new technology. This is a reduction of 288 tons of $\mathrm{CO}_{2} / \mathrm{yr} / \mathrm{unit}$.

Economic savings result from reduced fuel usage, and replacement of traditional raw materials with waste glass. The average 2001 industrial natural gas price of $\$ 4.86 / 1000$ cu.ft. was used in the calculations. With this gas price, the cost of fuel for 
traditional tile manufacturing is $\$ 64,600 / y r /$ unit, which is reduced to $\$ 40,700 / y r /$ unit with the new technology, saving $\$ 23,900 /$ yr/unit.

Even greater savings result from utilizing waste glass as raw material. Traditional ceramic tile raw materials of clay, flint, feldspar, etc. cost $\$ 125 /$ ton in 1997 , which amounts to $\$ 250,000 / \mathrm{yr} / \mathrm{unit}$. The cost of waste glass varies significantly from no cost (or even negative cost) to as much as $\$ 100 /$ ton, depending on the type of waste glass and region of the country. For the calculations $\$ 50 /$ ton was used, which results in $\$ 100,000 / y r /$ unit for waste glass raw material. This is a savings of $\$ 150,000 / y r /$ unit for raw materials.

The combined cost of fuel and raw materials for the new technology is $\$ 140,700 / y r / u n i t$ compared to $\$ 314,600 / y r /$ unit for traditional tile manufacturing, saving $\$ 173,900 / y r /$ unit. The data on savings per installed unit presented in this section are used in the next section to calculate the total savings based on market estimates.

Table IV - Energy, Environmental, and Economic Savings

\begin{tabular}{|c|c|c|}
\hline & $\begin{array}{l}\text { Traditional Ceramic Tile } \\
\text { Manufacturing }\end{array}$ & New Technology \\
\hline Installed Unit & $\begin{array}{l}\text { Tile process producing } \\
\text { one million sq.ft./yr }\end{array}$ & $\begin{array}{l}\text { Tile process producing } \\
\text { one million sq.ft./yr }\end{array}$ \\
\hline \multicolumn{3}{|l|}{ Energy Savings: } \\
\hline $\begin{array}{l}\text { Energy Consumption } \\
\text { (from fuel usage) }\end{array}$ & 13.3 billion $\mathrm{Btu} / \mathrm{yr} / \mathrm{unit}$ & 8.4 billion Btu/yr/unit \\
\hline \multicolumn{3}{|l|}{ Environmental Savings: } \\
\hline Raw Materials Consumed & $\begin{array}{l}2000 \text { tons/yr/unit of } \\
\text { clay, flint, feldspar, etc. }\end{array}$ & $\begin{array}{l}2000 \text { tons/yr/unit of } \\
\text { waste glass }\end{array}$ \\
\hline $\begin{array}{c}\mathrm{CO}_{2} \text { Emissions from } \\
\text { combustion of fuel }\end{array}$ & 779 tons $\mathrm{CO}_{2} / \mathrm{yr} / \mathrm{unit}$ & 491 tons $\mathrm{CO}_{2} / \mathrm{yr} /$ unit \\
\hline \multicolumn{3}{|l|}{ Economic Savings: } \\
\hline Cost of Fuel & $\$ 64,600 / y r / u n i t$ & $\$ 40,700 /$ yr/unit \\
\hline Cost of Raw Materials & $\$ 250,000 / y r /$ unit & $\$ 100,000 / y r /$ unit \\
\hline $\begin{array}{l}\text { Cost of Fuel and Raw } \\
\text { Materials }\end{array}$ & $\$ 314,600 / y r /$ unit & $\$ 140,700 / y r / u n i t$ \\
\hline
\end{tabular}




\section{MARKET ESTIMATES / TECHNICAL TRANSFER ACTIVITIES}

Estimates for introduction of the new technology into the U.S. ceramic tile market are provided in Table V. As discussed in the last section a unit consists of a manufacturing plant producing one million sq.ft. of tile per year. Thus, the data listed in rows A and B for number of units also correspond to millions of sq.ft. of tile production. The U.S. tile market data in row A is based on estimates from "The U.S. Ceramic Tile Market”, 2001 Edition, published by Market Studies, Raleigh, NC. The market estimates listed are based on a $6.2 \%$ annual growth rate.

From 1975-1999, the U.S. tile market increased an average of 7.8\%/yr, and from 1994-1999 increased 10.3\%/yr. Even with these large growth rates, the U.S. consumption per capita of ceramic tile is relatively low compared to many other countries, and thus there is still considerable future growth potential. From these estimates, the U.S. tile market will reach 8.7 billion sq.ft. in 2022. Ceramic tile energy consumption from fuel usage of 13,300 Btu/sq.ft. results in 34.7 trillion Btu in 2002, increasing to 116 trillion Btu in 2022. These values are for the total ceramic tile consumed in the U.S., of which only about one-third is manufactured in the U.S.

The tile market is large enough to utilize large volumes of waste glass, even with relatively small market penetration. Estimates of market penetration for the new technology are provided in row B of Table V. Five years after completion of the project (in 2007) 35 installed units of the new technology are estimated. This represents 35 million sq.ft. of tile, which is one percent of the estimated market. This amount of tile could be produced by one large tile manufacturing plant, however several plants producing 5-10 million sq.ft./yr are planned. Expansion to 280 million sq.ft./yr is estimated after 20 years (in 2022), which will be $3.2 \%$ of the market, less than the annual growth rate of the tile market. This amount of recycled-glass tile will consume 1.12 billion lbs/yr of waste glass, save 1.37 trillion Btu of energy, lower fuel and raw material costs by 48.7 million dollars, and reduce $\mathrm{CO}_{2}$ emissions by 80,600 tons/yr. These savings are listed in rows D-G of Table $\mathrm{V}$, along with the savings for earlier years.

A plan for commercialization of the technology has been developed. The plan focuses on licensing the technology to glass, tile, and/or waste glass processing companies. A demonstration plant producing 500,000 square feet of tile per year using 1000 tons of recycled glass was designed, as previously discussed in Section III.I. Initial discussions with selected companies have been conducted. 
Table V - Commercialization of the New Technology

\begin{tabular}{|c|c|c|c|c|c|}
\hline \multirow[b]{2}{*}{ Category } & \multicolumn{5}{|c|}{ U.S. Market } \\
\hline & $\begin{array}{c}\text { Project } \\
\text { Completion } \\
\text { Year } \\
(2002) \\
\end{array}$ & $\begin{array}{c}5 \text { Years } \\
\text { after } \\
\text { Completion } \\
(2007) \\
\end{array}$ & $\begin{array}{c}10 \text { Years } \\
\text { after } \\
\text { Completion } \\
(2012)\end{array}$ & $\begin{array}{c}15 \text { Years } \\
\text { after } \\
\text { Completion } \\
(2017) \\
\end{array}$ & $\begin{array}{c}20 \text { Years } \\
\text { after } \\
\text { Completion } \\
(2022) \\
\end{array}$ \\
\hline $\begin{array}{l}\text { (A) Total Number of Units } \\
\text { in U.S. Market } \\
\text { (Addressable Market) }\end{array}$ & 2,610 & 3,530 & 4,770 & 6,440 & 8,700 \\
\hline $\begin{array}{l}\text { (B) Total Number Installed Units } \\
\text { using New Technology } \\
\text { (Capturable Market) }\end{array}$ & 0 & 35 & 70 & 140 & 280 \\
\hline $\begin{array}{l}\text { (C) Market Penetration }= \\
\mathrm{B} / \mathrm{A} \times 100 \%\end{array}$ & 0 & 1.0 & 1.5 & 2.2 & 3.2 \\
\hline \multicolumn{6}{|l|}{$\begin{array}{l}\text { Savings from Waste Glass } \\
\text { based Tile Production }\end{array}$} \\
\hline (D) Energy Savings (Billion Btu) & 0 & 172 & 343 & 686 & 1,370 \\
\hline $\begin{array}{l}\text { (E) Raw Materials Replaced with } \\
\text { Waste Glass (Million lbs) }\end{array}$ & 0 & 140 & 280 & 560 & 1,120 \\
\hline $\begin{array}{l}\text { (F) Reduction in } \mathrm{CO}_{2} \text { Emissions } \\
\text { (Tons } \mathrm{CO}_{2} \text { ) }\end{array}$ & 0 & 10,100 & 20,200 & 40,300 & 80,600 \\
\hline $\begin{array}{l}\text { (G) Savings in Cost of Fuel and } \\
\text { Raw Materials (Million \$) }\end{array}$ & 0 & 6.1 & 12.2 & 24.3 & 48.7 \\
\hline
\end{tabular}

